\title{
Is The Indian Stock Market A Casino?
}

Ted Azarmi, (E-mail: tazarmi@ csulb.edu), Albstadt-Sigmaringen University, Germany

Daniel Lazar, (E-mail: daniel_lazar@postmark.net), Loyola College, India

Joseph Jeyapaul, (E-mail: j_joseph@ postmark.net), Sherubtse College, Bhutan

\begin{abstract}
This paper examines the empirical association between stock market development and economic growth for a period of ten years around the Indian market "liberalization" event. We find no support for the hypothesis that the Indian stock market development is associated with the economic growth in that country during the entire event study period of 1981 to 2001. We find support for relevance of stock market to econmic development during the pre-liberalization sub-period. We also find a negative correlation between stock market development and economic growth for the postliberalization period. We offer a number of hypotheses consistent with the inverse relationship between growth and stock market development in the post-liberalization period. In particular, our results are consistent with the suggestion that the Indian Stock market is a casino for the sub-period of post liberalization and for the entire ten-year event study period.
\end{abstract}

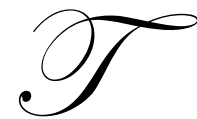

here are two different points of view regarding the role of the financial system for a country's economic growth: 1) the financial system is relevant and it matters to a country's growth and 2) it is irrelevant. We term these views as the relevance and the irrelevance hypothesis. The view that the stock market is a Casino is a consequence of the assertion that the financial system does not matter to a country's growth.

In an early articulation of the relevance hypothesis, Walter Bagehot (1873) and John Hicks (1969) argue that the British financial system played a critical role in facilitating industrialization in England by allowing for the mobilization of capital for "immense works". Similarly, Joseph Schumpeter (1912) asserts that well functioning banks help facilitate economic growth by promoting technological innovation through identifying and funding entrepreneurs with the best chance of successfully implementing innovative products and production processes. Let us term the above two assertions as the savings mobilization and the innovation hypothesis.

An extension of the above views to today's markets implies that financial institutions such as central banks, commercial banks, mutual funds, investment banking firms, and brokerage houses contribute to economic growth of a country by utilizing a variety of financial instruments (domestic and foreign currency, demand deposits, stocks, bonds, and derivative securities) to facilitate trade in goods and services and to funnel resources from savers to investors. In addition, by providing payment services, mobilizing savings, allocating credit, and allowing participants to pool, exchange, and price risk, the financial system improves the flow of information, the allocation of resources, and the management of firms in ways that promotes economic development. We will attempt to capture and explore these additional roles of the financial system by postulating a set of hypothesis termed: liquidity, diversification, information, and control hypothesis.

There is some empirical evidence in support of the relevance hypothesis. For example, Goldsmith (1969) and McKinnon (1973) document a close relationship between financial and economic development for a number of countries.

Policy implications of the view that financial services positively affect growth, range from a prescription for lack of government intervention in finance to a call for intervention in particular circumstances. For example, Roubini and Sala-I-Martin (1991) and Levine (1991) argue that official interference in financial activities may retard growth. 
On the other hand, Stiglitz (1989) shows that under certain conditions, the existence of market imperfections implies that certain forms of official intervention improve resource allocation and corporate control.

A good articulation of the irrelevance view may be found in Joan Robinson (1952), who declares that "where enterprise leads finance follows". According to this view, economic development creates demand for particular types of financial arrangements, and a country's financial system automatically responds to these demands. Another manifestation of this view is the belief that the finance-growth relationship is neither significant nor worthy of academic resources. Robert Lucas (1988), states that economists badly overemphasize the role of finance in economic growth. Other development-economists have expressed their skepticism about the significance of the role of finance by ignoring it all together. For example, a collection of essays from the 'pioneers of development economics', including three Nobel Laureates, in Gerald Meir and Dudley Seers (1984) does not even mention finance. Similarly, a review of development economics by Nicholas Stern (1989) does not discuss financial systems, even in a section that lists other omitted topics.

The Keynesian thesis that the stock market is a Casino may be viewed as a consequence of the general assertion that the financial system does not matter to a country's growth. The alternative relevance hypothesis may be stated as follows: the stock market serves significant economic functions even in those economies in which there already exists a well-developed banking sector.

The relevance hypothesis may be established on the grounds that equity and debt financing are not perfect substitutes in imperfect markets. For example, equity financing may play a role in mitigating the conflicts of interest that arise between different stakeholders within the firm thereby causing a reduction in agency costs, within an economy under asymmetric information and uncertainty. The stock market's contribution may then be tied to a reduction in asymmetric information. We term this role of the stock market the information hypothesis. Specifically, Demirguc-kunt and Masksimovic (1995) argue that stock trading transmits information about a firm's prospects to potential investors and creditors.

A detailed articulation of the relevance hypothesis applied to the stock market may be found in William Ryrie (1990), who states that the stock market contributes to economic development through a) being an initial source and a facilitator of equity finance, b) being an efficient mechanism for spreading ownership widely in the population and mobilizing the savings of the population, c) being a highly efficient mechanism for allocating capital to productive use and d) facilitating a link between the capital markets of a particular country and the markets of the industrial world.

The role of the stock market as an initial source and a facilitator of equity finance may be analyzed and further articulated by arguing that equity finance is necessary and has a strong positive supportive effect for the formation of entrepreneurial and small to midsize enterprises (SMEs). A generalization of this argument is as follows: to benefit from the wealth gains associated with an American-style free-market economy in contrast to a centrally planed economy, a country such as China needs to have a functioning stock market. We term this role of the stock market as "the equity matters" hypothesis. Ryrie's assertion regarding the stock market being an efficient mechanism for spreading ownership widely in the population can be reinterpreted in terms of economic liberalization of pension holdings and efficient inter-generational transfers through equal access to corporate ownership for everyone. This is a gain associated with creating a complete market, which can be wealth-increasing in an imperfect economy. We term this role as the "dispersed ownership" hypothesis. Ryrie's assertion regarding mobilizing the savings of the population is captured by our "savings mobilization" hypothesis. Ryrie's item c) above is another articulation of our innovation hypothesis. The world linkage argument in part d) is particularly interesting in relation to emerging capital markets. This role is captured by our diversification hypothesis.

The global growth of stock markets and the emerging market boom have attracted the attention of academics, practitioners, and policy makers. There is an academic literature focused on measuring the benefits of holding a globally diversified portfolio. A number of countries, including India and China, are reforming regulations and laws to foster capital market development and attract foreign portfolio flows. 
There also is a theoretical literature that suggests that a well-developed stock market may promote risk diversification, liquidity, information processing, and capital mobilization and that these services may accelerate longrun growth. For example, see Levine (1991), Greenwood and Smith (1994), Obstfeld (1994). In addition,, Greenwood and Smith (1994) demonstrate that large stock markets can lower the cost of mobilizing savings and thereby facilitate investment in the most productive technologies (the innovation hypothesis and the savings mobilization hypothesis). Bencivenga, Smith and Starr (1996) and Levine (1991) argue that stock market liquidity is important for economic growth. That is, corporate net-present-value positive projects may require a long-run commitment of capital that does not match savers' shorter investment horizons. A liquid equity market mitigates this miss-matched horizon problem by providing a long horizon asset to savers that may be quickly and inexpensively converted to a short horizon asset through a cost-effective liquidation. We term this economic role of the stock market as the liquidity hypothesis. The stock market also provides entrepreneurs with liquidity and the opportunity to diversify their portfolios.

Kyle (1984) and Holmstrom and Tirole (1993) show that a liquid stock market increases incentives for getting information about firms and leads to improved corporate governance. Obstfeld (1994) shows that international risk sharing through internationally integrated stock markets improves resource allocation and may accelerate the rate of economic growth. These assertions several hypotheses posited within this paper. That includes our liquidity, information, control, and savings mobilization hypothesis.

There are theoretical grounds for the irrelevance hypothesis applied to the stock market. Mayer (1988) points out that large stock markets in general are unimportant sources of corporate finance. Stiglitz (1993) argues that stock market liquidity does not enhance incentives for acquiring information about firms or improving corporate governance. Devereux and Smith (1994) suggest that greater risk sharing through internationally integrated stock markets may reduce saving rates and slow economic growth. Shleifer and Summers (1998) and Morck, Shleifer, and Vishny's (1990) suggest that stock market development may hurt economic growth by easing counterproductive corporate takeovers. This last effect is termed the control hypothesis within our paper.

This paper contributes to the above literature by examining the empirical link between Indian stock market development and that country's economic growth. This link also has positive policy implications for India. For example, according to M. R. Mayya, former executive director of Bombay Stock Exchange (BSE), "Preindependence, the growth of the capital markets in India was stunted by the policies of the British government, which was not interested in India's economic growth. Post-independence, it was the emphasis on the public sector, which prevented the private sector from realizing its full potential."

We build on Levine and Zervos (1996) study of stock market development and economic growth by focusing on India for a ten-year stock market liberalization period. We also study both the pre and post-liberalization periods individually. For approximately that entire period, there has been an emphasis on reviving the Indian capital markets, with the hope that economic growth would be achieved through attracting foreign institutional investors (FIIs) to a well functioning stock market and through facilitating economic freedom. Our study is relevant to the recent effort to revive the Indian stock market and the implications of that effort.

\section{THE IRRELEVANCE HYPOTHESIS AND ITS PROXY VARIABLES}

Let us formulate our null irrelevance hypothesis as follows: there is no significant relationship between stock market development and economic growth in India. This hypothesis may be written as follows:

\section{$\mathbf{H}_{\mathbf{0}}: \mathrm{GROWTH} \neq \mathrm{STOCK}$}

Where, GROWTH is the time series of real per capita GDP for a given relevant period and STOCK is an index or a proxy for stock market development over the same period.

Let us consider the following three measures of the stock market development, which are commonly utilized in literature (for example see, Pagano (1993), Demirguc-Kunt and Levine (1995)): 1) the ratio of stock market capitalization to GDP, which we term the "MARKET CAPITALIZATION", 2) the ratio of trade volume to GDP, 
called "TOTAL VALUE TRADED" and 3) the ratio of the value of shares traded to market capitalization, labeled as "TURNOVER". The variable MARKET CAPITALIZATION is a proxy measure for the extent that the stock market allocates capital to investment projects and the opportunities for risk diversification that it provides investors. TOTAL VALUE TRADED and TURNOVER are indicators of market liquidity. The former measures the investors' ability to trade economically significant positions on a stock market, whereas the latter is an indicator of the liquidity of assets traded within a market. In calculating the MARKET CAPITALIZATION variable, the stock market capitalization is adjusted for the size of the economy to arrive at a size-adjusted variable that more accurately measures and therefore is a better proxy for the relative level of stock market development. A high value for TOTAL VALUE TRADED may result from high trading activity in certain active stocks, while there may also be a significant number of relatively inactive shares listed on the same stock exchange. In this case, a better indicator of stock market activity is the turnover ratio.

Let us also consider a proxy measure of stock market volatility, called VOLATILITY. This variable is defined as the standard deviation of the last twelve-month market returns. VOLATILITY is a measure of risk that is of interest both to our academic studies and the profession and practice of finance. Even though VOLATILITY does not proxy for stock market development directly, it has been considered herein on the grounds of the above-mentioned interest and relevance. In other words, theoretically, a greater volatility is not necessarily a sign of increased stock market development. However, we refer to "less volatility" as reflecting "greater stock market development" for its practical relevance and for simplicity. To measure the degree of market concentrations, we compute the share of market capitalization that is accounted for by the ten largest stocks and call this measure CONCENTRATION.

In addition to the above proxies, institutional aspects, such as legal and accounting rules and market regulations, may also proxy for the degree of development of a stock market. Developed stock markets of the industrialized countries such as USA, Japan, and Germany, generally have well functioning supervisory boards, information disclosure rules, internationally accepted accounting standards, low transaction costs, and short settlement times. In addition, foreign investors may enter and exit these markets with ease and there are often reasonable withholding taxes on foreign capital gains and dividend income. Unfortunately, these proxies are too qualitative and subjective in nature to allow for standard statistical analysis. This problem may be partially remedied by assigning values to institutional indicators based on the information collected from the experts.

To compute a single composite proxy for stock market development, we calculate indices based on the average of the values of several stock market development proxies as proposed by Demirguc-Kunt and Levine (1996). Let us aggregate the information contained in market capitalization, total value traded, and turnover proxies with an index called INDEX 1. This index is calculated in a two-step procedure. First, we compute the means-removed values for market capitalization, total value traded, and turnover over the relevant study period. Second, we compute a simple mean of these three means-removed values in order to obtain an overall index of stock market development called INDEX 1.

We calculate an INDEX 2 from the average of the means-removed values of market capitalization, total value traded, turnover, and market concentration. Recall that market concentration is proxied by the share of market capitalization that is accounted for by the ten largest stocks. In this proxy of market concentration, large values indicate less stock market development. In order to achieve consistency with other measures, we multiply the concentration values by negative 1 prior to computing the composite index.

According to Levine and Zervos (1996), stock market liquidity is a robust predictor of real per capita GDP growth only after controlling for initial income, initial investment in education, political stability, fiscal policy, openness to trade, and macroeconomic stability. In Levine and Zervos study, the remaining stock market development proxies do not exhibit a robust link with long-run growth. In particular, volatility is insignificantly correlated with growth in most specifications in that study. Similarly, market size, international integration, capital accumulation, productivity improvements, and private savings rates are not robustly linked with growth within the Levine and Zervos (1996) framework. 


\section{THE EMPIRICAL STUDY AND CONTROL VARIABLES}

In order to empirically evaluate whether the index of stock market development (STOCK) is linked to economic growth, we use a time-series growth regression. This empirical analysis is done over the following three relevant periods: first an analysis over the entire study period of 1981 to 2001, second a study over the preliberalization period of 1981 to 1990 , and finally a post-liberalization study over the 1991 to 2001 period. The structure of our regression equation is the following:

GROWTH $=\alpha \mathrm{X}+\beta(\mathrm{STOCK})+\mathrm{u}$

Where, the dependent variable, GROWTH, is the time series of real per capita GDP over the period of the study. $X$ is a set of control variables, $\alpha$ is a vector of coefficients for the variables in $X, \beta$ is the estimated coefficient of the STOCK variable, and $u$ is an error term.

The variable $\mathrm{X}$ is used to control for other factors besides STOCK that may account for economic growth. $\mathrm{X}$ includes the agricultural contribution to GDP called AGRICULTURAL; industrial contribution to GDP termed INDUSTRIAL; financial depth (DEPTH) measured by M3 divided by GDP; the ratio of government expenditure to GDP (GOVERMENT), the ratio of total bank demand deposit claims to GDP (BANK); total foreign trade measured by aggregating total imports and export values (TRADE); and the rate of inflation (INFLATION).

In particular, agriculture is an important sector of the Indian economy from the perspective of poverty alleviation and generating employment. Therefore, this variable is controlled for in our empirical study. After all, agriculture accounted for about 24.2 percent of India's national income in the 2000-2001 period. This figure is about half the figure for the share of agriculture in the national income of India in the 1950-1951 period, when it was 56.6\%. However, there has been only a small decline in the workforce employed in the agriculture sector over that 50-year period. In 1961, 75.9 percent of the total workforce was engaged in agriculture, and in 1999-2000 that figure was reduced to 59.9 percent. Despite the decrease in the percentage figures, total employment in agriculture remained 237.8 million (See the editorial notes on developments in Indian agriculture: some issues (2002-2003) by Census of India).

Industrial contribution to GDP has increased substantially from 11.8 per cent of GDP in 1950-51 to 24.6 percent in 1990-91. In addition, the composition and type of industrial activity has undergone great transformation in the last 50 years (see the editorial notes on industrial development and policies since independence 2002-2003).

We control for a set of macroeconomic variables to account for the connection between macroeconomic policy and economic activity. The inclusion of these control variables is motivated by Levine and Zervos (1993) and Fischer (1993). In particular, the later study provides evidence for a strong connection between macroeconomic policy and economic activity that can be measured by the GOVERNMENT and the INFLATION variable. The BANK-variable controls for the impact of individual savings on economic-growth.

\section{THE DATA}

The data set on stock market size, liquidity, concentration, and volatility for a twenty-one year period from 1981 to 2001, is obtained from Bombay Stock Exchange (BSE) primary publications, its website, stock exchange reviews, and annual reports. The data for institutional indicators have been collected from a questionnaire survey of experts. Data on real per capita GDP (GROWTH), GOVERMENT, INFLATION, AGRICALTURE, INDUSTRY, DEPTH, BANK and TRADE is from RBI's handbook of Statistics on Indian Economy for 2001. Data on percentage contribution of agriculture and industry to GDP and work force in agriculture is obtained from Census of India.

\section{THE RESULTS}

Table 1 summarizes the results of our time-series growth regression study of the real per capita GDP on Index 1 as a proxy for the stock market development while controlling for the contribution of agricultural, industrial 
output, financial depth, bank savings, trade volume, inflation, and government expenditure on GDP. Index 1 is a composite proxy consisting of the mean-removed values of stock capitalization, liquidity, and two measures of turnover (the ratio of shares traded by market capitalization and the ratio of total value traded by GDP).

Table 1 shows that over the entire study period of $1981-2001$, there has been no statistically significant association between stock market development and economic growth in India. However, over the pre-liberalization period of 1981-1990, there was a statistically significant and positive relation between stock market development and economic growth in India at $\mathrm{p}=0.0791 *$ (with a 92 percent confidence interval). In contrast, Table 1 shows that during the post-liberalization period of 1991-2001, the Indian stock market had a significant negative relationship with the economic growth of India at $\mathrm{p}=0.0333^{* *}$. One possible way to interpret this seamingly contradictory result is to focus on the negative correlation of growth and stock market development in the post-liberalization period and the insignificance of the relationship over the entire study period, and conclude that these two period's results indicate that the stock market does not contribute to the growth of economy in India. This interpretation is consistant with the theories advanced by Shleifer and Summers (1998), Morck, Shleifer and Vishny's (1990), Stiglitz (1993) and Mayyer (1988). That is, stock markets are unimportant sources of finance; stock market liquidity does not enhance incentives for acquiring information; internationally integrated stock markets can actually reduce saving rates and slow economic growth; and stock market development can hurt economic growth by easing counterproductive corporate takeovers.

The results of our study in India are different from the cross-country regressions done by Levine and Zervos (1993) that show a significant relation between stock market development and economic growth from pooled data over several countries including India. This difference may be attributed to shortcomings of cross sectional studies, which are well understood and articulated in Levine and Zervos (1993). In particular, these problems include measurement, statistical, and conseptual issues.

Another way to approach this problem is to follow the lead that was provided in the concluding remarks of Levine and Zervos (1993), with a call for additional research based on a careful case study of the stock market, in order to identify the causal interaction between stock market development and economic growth. Let us focus on a summary of developments in the Indian stock market in order to atempt to interpret our results in the light of that study.

The post-liberalization period (ninteen nineties) in India has been characterized by the following domestic changes: a new industrial policy; introduction of online trading; emergence of a new market regulator called the Securities \& Exchange Board of India (SEBI); the integration of the Indian stock market with global exchanges; arrival of foreign institutional investors (FIIs); permitting foreign brokers to trade on Indian stock markets; and a primary market boom and bust.

In particular, our results that during the post-liberalization period of 1991-2001, the development of Indian stock market had a significant negative relationship with the economic growth of India, may be attributed to a number of securities scams involving brokers as well as bankers in this period. These scams included one of largest setbacks in the Indian capital market's history. Considerable amount of capital was diverted from the banking sector to the stock markets by individual traders, such as Harshad Mehta, Hiten Dalal, Bhupen Dalal, and others. There was a large bubble in Indian stock market prices in early 1990's, which was followed by a market collapse in April 1992, causing huge losses for thousands of investors.

The post-liberalization perriod may also be described as the decade of radical changes in the Indian trading mechanism. For the first time in its history of over 115 years, BSE faced competition. The competetive presure came from computerized stock exchanges like OTCEI and NSE. As a consequence, BSE followed NSE by speeding up a pending computerization program. BSE allowed for online trading in June 1995. In response to these competetive presures, BSE also reduced its settlement cycle from 14 days to 7 days and extended its BOLT (BSE online Trading) beyond the city limits of Bombay. This change in competetive environment may have also contributed to the observe negative association between economic growth and stock market development in this period. 
In the post-liberalization period, the regulator SEBI for a second time in its history, banned Badla trading in certain stocks in December 1993 (Badla trading is an Indian method of purshasing stocks on margin where the interest rate is a function of the demand for Badla trading in a particular market). Based on the proposals of the Patel committee, SEBI permitted badla trading on BSE with certain restrictive checks and balances in January 1996 . These changes may have also created an anamoly which may also account for our observed negative correlation.

Table 1: Stock Market Development and real per capita GDP (STOCK = Index 1)

\begin{tabular}{|c|c|c|c|}
\hline & $\begin{array}{c}\text { Whole study period } \\
(1981-2001)\end{array}$ & $\begin{array}{c}\text { Pre- Liberalization } \\
(1981-1990)\end{array}$ & $\begin{array}{c}\text { Post- Liberalization } \\
(1991-2001)\end{array}$ \\
\hline \multirow{3}{*}{ Constant } & -1.054733 & -4.230628 & -10.01635 \\
\hline & $(-0.755572)$ & $(-18.35990)$ & $(-4.475963)$ \\
\hline & {$[0.4645]$} & {$[0.0346] * *$} & {$[0.0465] * *$} \\
\hline \multirow[t]{3}{*}{ Inflation } & -0.012694 & -0.006703 & -0.000989 \\
\hline & $(-2.709696)$ & $(-3.589107)$ & $(-0.185991)$ \\
\hline & {$[0.0190]^{* *}$} & {$[0.1730)$} & {$[0.8696]$} \\
\hline \multirow[t]{3}{*}{ Agriculture } & 0.770295 & 5.949388 & 5.049318 \\
\hline & $(0.424759)$ & $(14.26328)$ & $(3.556214)$ \\
\hline & {$[0.6785]$} & {$[0.0446) * *$} & {$[0.0708] *$} \\
\hline \multirow[t]{3}{*}{ Industry } & -0.251125 & 6.252853 & 10.90291 \\
\hline & $(-0.078641)$ & $(8.026651)$ & $(4.650645)$ \\
\hline & {$[0.9386]$} & {$[0.0789] *$} & {$[0.0433] * *$} \\
\hline \multirow[t]{3}{*}{ Depth } & 7.964164 & -2.416057 & 8.079720 \\
\hline & $(1.769899)$ & $(-3.084032)$ & $(4.093787)$ \\
\hline & {$[0.1021]$} & {$[0.1996]$} & {$[0.0548] *$} \\
\hline \multirow[t]{3}{*}{ Government } & -2.245100 & -2.934073 & 6.636610 \\
\hline & $(-0.788586)$ & $(-10.10627)$ & $(2.375563)$ \\
\hline & {$[0.4457]$} & {$[0.0628]^{*}$} & {$[0.1407]$} \\
\hline \multirow[t]{3}{*}{ Bank } & -4.604308 & 10.62844 & 4.940887 \\
\hline & $(-0.928525)$ & $(13.67645)$ & $(1.261981)$ \\
\hline & {$[0.3714]$} & {$[0.0465] * *$} & {$[0.3342]$} \\
\hline \multirow[t]{3}{*}{ Trade } & 0.931346 & 1.293152 & -0.216384 \\
\hline & $(0.364571)$ & $(4.495765)$ & $(-0.128439)$ \\
\hline & {$[0.7218]$} & {$[0.1393]$} & {$[0.9096]$} \\
\hline \multirow[t]{3}{*}{ Stock } & 0.002490 & 0.024430 & -0.069955 \\
\hline & $(0.055878)$ & $(8.003643)$ & $(-5.338105)$ \\
\hline & {$[0.9564]$} & {$[0.0791] *$} & {$[0.0333] * *$} \\
\hline
\end{tabular}

Note: ( $\mathrm{t}$ - statistic are in parentheses); [P values are in brackets]; an * indicates statistical significance at $10 \%$ level and $* *$ at $5 \%$ level; the dependent variable is real per capita GDP.

In the pre-liberalization period of 1981-1990 participation of retail investors in the Indian stock market grew. Practitioners characterize this period as a period of speculative stock trading in India. In 1986, Badla under the name of "hand-delivery contracts-specified shares" was reintroduced to the Indian stock market after a period of prohibition dating back to June 1969. In this period, the definition of hand-delivery was modified; the period of the performance for hand-delivery was extended by 5 days to 14 days; and the overall margin buying period for Badla had a limit of 90 days. Practitioners atribute a boom in Sensex index from 272 points to 665 from 1984 to 1986 to the reintroduction od Badla. Individual investor participation also increased in this period. Overall, the pre-liberalization period is viewed as a period of stock market growth in India. These stylized facts, may explain our results that the stock market growth and economic growth are correlated in the pre-liberalization period. 
In order to test the robustness of our results to concentration defined as the share of top ten companies market capitalization to total market capitalization, we recalculate our regression based on a new composite proxy of stock market called Index 2. This index consists of the same three averages of means-removed values of market capitalization to GDP, total values of shares traded to GDP, and total values of shares traded to market capitalization as appear in Index 1, with the addition of the variable concentration.

Table 2: Stock Market Development and real per capita GDP (STOCK= Index 2)

\begin{tabular}{|c|c|c|c|}
\hline & $\begin{array}{c}\text { Whole study period } \\
(1981-2001)\end{array}$ & $\begin{array}{c}\text { Pre-Liberalization } \\
(1981-1990)\end{array}$ & $\begin{array}{c}\text { Post-Liberalization } \\
(1991-2001)\end{array}$ \\
\hline \multirow[t]{3}{*}{ Constant } & -1.044661 & -4.214555 & -10.33100 \\
\hline & $(-0.760659)$ & $(-15.63635)$ & $(-4.662607)$ \\
\hline & {$[0.4615]$} & {$[0.0407] * *$} & {$[0.0430] * *$} \\
\hline \multirow[t]{3}{*}{ Inflation } & -0.012698 & -0.006499 & -0.000400 \\
\hline & $(-2.710317)$ & $(-2.957724)$ & $(-0.076435)$ \\
\hline & {$[0.0189] * *$} & {$[0.2076]$} & {$[0.9460]$} \\
\hline \multirow[t]{3}{*}{ Agriculture } & 0.760990 & 5.937163 & 5.249117 \\
\hline & $(0.422367)$ & $(12.17893)$ & $(3.737815)$ \\
\hline & {$[0.6802]$} & {$[0.0522] *$} & {$[0.0647] *$} \\
\hline \multirow[t]{3}{*}{ Industry } & -0.276874 & 6.264024 & 11.25881 \\
\hline & $(-0.088607)$ & $(6.884152)$ & $(4.855002)$ \\
\hline & [0.9309] & {$[0.0918] *$} & {$[0.0399] * *$} \\
\hline \multirow[t]{3}{*}{ Depth } & 7.941923 & -2.582809 & 7.791088 \\
\hline & $(1.763241)$ & $(-2.775486)$ & $(4.028863)$ \\
\hline & [0.1033] & {$[0.2202]$} & {$[0.0564] *$} \\
\hline \multirow[t]{3}{*}{ Goverment } & -2.237179 & -2.900600 & 6.967259 \\
\hline & $(-0.785389)$ & $(-8.498448)$ & $(2.534894)$ \\
\hline & {$[0.4475]$} & {$[0.0746] *$} & [0.1267] \\
\hline \multirow[t]{3}{*}{ Bank } & -4.585706 & 10.78246 & 5.587814 \\
\hline & $(-0.920938)$ & (11.71482) & $(1.441031)$ \\
\hline & [0.3752] & {$[0.0542] *$} & [0.2863] \\
\hline \multirow[t]{3}{*}{ Trade } & 0.940731 & 1.325541 & -0.117131 \\
\hline & $(0.369772)$ & $(3.964195)$ & $(-0.071450)$ \\
\hline & {$[0.7180]$} & {$[0.1573]$} & {$[0.9495)$} \\
\hline \multirow[t]{3}{*}{ Stock } & 0.002617 & 0.032723 & -0.095770 \\
\hline & $(0.044396)$ & $(6.838041)$ & $(-5.524451)$ \\
\hline & {$[0.9653]$} & {$[0.0924] *$} & {$[0.0312] * *$} \\
\hline
\end{tabular}

Note: ( $\mathrm{t}$ - statistic are in parentheses); [P values are in brackets]; an * indicates statistical significance at $10 \%$ level and $* *$ at $5 \%$ level; the dependent variable is real per capita GDP.

Table 2 shows the results of our time-series growth regression study of the real per capita GDP on Index 2 as a proxy for the stock market development while controlling for the contribution of agricultural, industrial output, financial depth, bank savings, trade volume, inflation, and government expenditure on GDP. This table shows that our study of stock market growth proxied by Index 2 results to similar relation with the economic growth as it was documented with Index 1. That is, there is no significant statistical relation for the whole study period $(\mathrm{p}=0.9653)$; there is a significant positive relation for the pre-liberalization period $\left(\mathrm{p}=0.0924^{*}\right)$; and a statistically significant negative post-liberalization stock market-growth relation $(\mathrm{p}=0.0312 * *)$. The robustness of our result to incusion of the market concentration is consistant with the literature. 


\section{THE CONCLUSION}

This paper empirically evaluats the relation between stock market development and economic growth in India. The data suggest that stock market development in India is not associated with economic growth over a twentyone year study period. Once we account for the liberalization event, the time series growth regressions imply a link between stock market development and economic growth. The fact that the link is positive for the pre-liberalization period and negative for the post-liberalization period may account for lack of sinificance over the entire period. That is, in aggregare the positive and negative relations do cancle out

This paper is not intended as a commentary on policy. However, our results are consistant with the assertion that the Indian stock market may be viewed as a casino that is not contributing to the economic growth of the country. While stock market development is not correlated with economic growth for a twenty-one-year period, our contribution is to narrow the causes for lack of correlation to the events of post-liberalization period of ninteen-ninties. Additional future research is needs to identify the harmfull policy changes of that period and to prescribe policies that induce a strong relation between stock exchange and economic growth.

\section{REFERENCES}

1. $\quad$ Bagehot, Walter, Lombard Street. Homewood, IL: Richard D.Irwin, 1873 (1962 Edition).

2. Bencivenga, V. R, Smith, B. D, and R. M. Starr, "Equity markets, Transaction Costs, and Capital Accumulation: An Illustration," World Bank Economic Review, 1996.

3. Demirguc-kunt and V. Masksimovic, Stock market development and firm financing choices, World Bank, Washington, 1995.

4. Devereux and Smith, "International Risk Sharing and Economic Growth", International Economic Review, August 1994, 35 (4), pp. 535-50.

5. Diamond and Verrecchia, "Optimal Managerial Contracts and Equilibrium Security Prices," Journal of Finance, May 1982, 37, pp.275-287.

6. Fischer, "The Role of Macroeconomic Factors in Growth". Journal of Monetary Economics, December 1993, 32 (3): 485-511.

7. Goldsmith, Raymond, W. Financial Structure and Development. New Haven, CT: Yale University Press, 1969.

8. Greenwood, J., and B. Smith, "Financial Markets in Development and the Development of Financial Markets," Journal of Economic Dynamics and Control, 1994.

9. $\quad$ Hicks, John, A Theory of Economic History, Oxford: Clarendon Press, 1969.

10. Holmstrom and Tirole, "Market Liquidity and Performance Monitoring," Journal of Political Economy, August 1993, 101 (4), pp.678-709.

11. Kyle, "Market Structure, Information, Futures Markets, and Price Formation," in International Agriculture Trade: Advanced Readings in Price Formation, Market Structure, and Price Instability, edited by Gary G. Storey, Andrew Schmitz, and Alexander, Boulder, Colorado, Westview, 1984.

12. Laffont and Tirole, "Repeated Auctions of Incentive Contracts, Investment, and Bidding Parity with an Application to Takeovers," Rand Journal of Economics, winter 1988, 19, pp.516-537.

13. Levine, Ross, "Stock Markets, Growth, and Tax Policy", Journal of Finance, September 46 (4), p.1445-65, 1991.

14. Levine, Ross and Sara Zervos, "Stock Market Development and Long-Run Growth", World Bank Economic Review, Oxford University Press, vol. 10(2), pages 323-339, 1996.

15. Lucas, Robert E, "On the Mechanics of Economic Development", Journal of Monetary Economics, July 1988, 22 (1), pp.3-42.

16. Mayer, "New Issues in Corporate Finance," European Economic Review, 1988, 32, 1167-1188.

17. Mckinnon, Ronald I. Money and Capital in Economic Development, Washington, DC: Brookings Institution, 1973.

18. Meier, Gerald M. and Seers, Dudley, Pioneers in Development, New York: Oxford University Press, 1984.

19. Obstfeld, Maurice, "Risk-Taking, Global Diversification, and Growth," American Economic Review, 1994, December 84 (5), p.1310-1329. 
20. Pagano, "The flotation of companies on the stock market: a coordination failure model," European Economic Review 37, 1101-25.

21. Roubini, N and Sala-I-Martin, "The Relation between Trade Regime, Financial Development and Economic Growth," Mimeo, Yale University, 1991.

22. Ryrie, William, "Stock markets and their role in economic development," The Stock Exchange Review, February 1991(the text of the second P. J. Jeejeebhoy Memorial lecture, 1990).

23. Saint-Paul, Gilles, "Technological Choice, Financial Markets and Economic Development," European Economic Review, May 1992, 36 (4), pp.763-81.

24. Scharfstein, “The Disciplinary Role of Takeovers," Review of Economic Studies, April 1988, 55, pp.185-99.

25. Schumpeter, Joseph A, Theorie der Wirtschaftlichen Entwicklung, Leipzig; Dunker \& Humblot, 1912. (The Theory of Economic Development, 1912, translated by Redvers Opie. Cambridge, MA: Harvard University Press, 1934).

26. Shleifer and Summers, "Breach of Trust in Hostile Takeovers," in ed., A. Auerbach, Corporate Takeovers: Causes and Consequences, 1988, Chicago, University of Chicago Press, 33-56.

27. Stern, Nicholas, "The Economics of Development: A Survey," Journal of Money, Credit and Banking, May 1985, 17 (2), pp.133-52.

28. Stiglitz, J. "Financial Markets and Development." Oxford Review of Economic Policy, 1989, 5: 55-68.

29. Stiglitz, "The Role of the State in Financial Markets," Proceedings of the Annual Bank Conference on Development Economics, 1993, pp. 19-52. 